\title{
COMMENTARY
}

\section{Comments by the Auditing Standards Committee of the Auditing Section of the American Accounting Association on PCAOB Rulemaking Docket Matter No. 37: PCAOB Release No. 2011-006, Concept Release on Auditor Independence and Audit Firm Rotation}

Participating Committee Members:

Keith L. Jones, Jagadison K. Aier, Duane M. Brandon, Tina D. Carpenter, Lisa M. Gaynor, W. Robert Knechel, Mikhail B. Pevzner, Brad J. Reed, and Paul L. Walker

SUMMARY: In August 2011, the Public Company Accounting Oversight Board (PCAOB or Board) issued a concept release to solicit public comment on the potential direction of a proposed standard-setting project on means to enhance auditor independence, objectivity, and professional skepticism. The Concept Release sought comments on and explores in detail the possibility of mandatory audit firm rotation. The PCAOB provided for a 121-day exposure period (from August 16 to December 14, 2011) for interested parties to examine and provide comments on the concept release. The Auditing Standards Committee of the Auditing Section of the American Accounting Association provided the comments in the letter below (dated December 13, 2011) to the PCAOB on PCAOB Rulemaking Docket Matter No. 37: PCAOB Release No. 2011-006, Concept Release on Auditor Independence and Audit Firm Rotation.

Data Availability: Information about and access to the release are available at: http:// pcaobus.org/Rules/Rulemaking/Docket037/Release_2011-006.pdf

RE: PCAOB RULEMAKING DOCKET MATTER NO. 37: PCAOB RELEASE NO. 2011-006, CONCEPT RELEASE ON AUDITOR INDEPENDENCE AND AUDIT FIRM ROTATION 
Dear Board Members:

The Auditing Standards Committee of the Auditing Section of the American Accounting Association is pleased to provide comments on the PCAOB Rulemaking Docket Matter No. 37: PCAOB Release No. 2011-006, Concept Release on Auditor Independence and Audit Firm Rotation.

The views expressed in this letter are those of the members of the Auditing Standards Committee and do not reflect an official position of the American Accounting Association. In addition, the comments reflect the overall consensus view of the Committee, not necessarily the views of every individual member.

We hope that our attached comments and suggestions are helpful and will assist the Board. If the Board has any questions about our input, please feel free to contact our committee chair for any follow-up.

Respectfully submitted,

Auditing Standards Committee

Auditing Section-American Accounting Association

Contributors:

Chair-Keith L. Jones, George Mason University

Jagadison K. Aier, George Mason University

Duane M. Brandon, Auburn University

Tina D. Carpenter, The University of Georgia

Lisa M. Gaynor, University of South Florida

W. Robert Knechel, University of Florida

Mikhail B. Pevzner, George Mason University

Brad J. Reed, University of Southern Illinois

Paul L. Walker, University of Virginia

\section{RESPONSES TO SPECIFIC QUESTIONS IN THE RELEASE}

\section{Section III (D). General Questions}

Should the Board focus on enhancing auditor independence, objectivity, and professional skepticism? How significant are the problems in those areas relative to problems in other areas on which the Board might focus? Should the Board simply defer consideration of any proposals to enhance auditor independence, objectivity, and professional skepticism?

Auditor independence, objectivity, and professional skepticism are cornerstones of the audit profession, and the PCAOB should continue to focus on improving them to serve the interests of capital market participants and users of financial information. Given the evolving changes in accounting standards and increasing regulatory requirements for financial reporting, the Committee believes that there now is a greater need for the Board to consider ways to help improve auditors' judgments and mindsets in facing new challenges, to ensure that the financial statements continue to reflect a true and fair view of a company's performance, resources, and liabilities.

The Committee also recognizes that independence, objectivity, and professional skepticism are difficult to define and even harder to evaluate (other than when they obviously are lacking). Thus, any regulation is easily justified by simply waving at these concepts, because nobody would argue against improving independence, objectivity, and skepticism. So while they are certainly worthwhile goals, they are much more problematic as a guide to better practice, especially through 
regulation. The Board would be well served to pause and consider not just if more regulation is needed, but why current regulation is not achieving the desired level of independence, objectivity, and professional skepticism.

\section{Would audit firm rotation enhance auditor independence, objectivity, and professional skepticism?}

A mandatory audit firm rotation proposal is premised on two assumptions: (1) a long-term relationship between a company and its audit firm would impinge on the auditor's independence and impair their ability to be objective and neutral, and (2) mandatory audit firm rotation would resolve problems (if any) associated with long-term association between companies and their audit firms. The Committee believes that, while mandatory firm rotation could lead to improved perceptions of auditor independence, objectivity, and professional skepticism, there is no evidence or research that supports the PCAOB's conjectures.

Two recent studies performed subsequent to the passage of the Sarbanes-Oxley Act (e.g., Myers et al. 2003; Kaplan and Mauldin 2008) provide additional reasons to question the need for and benefit of mandatory audit firm rotation. In a sample of firm-years from 1988 to 2000, Myers et al. (2003) do not find evidence to support concerns about lower audit quality associated with longer auditor tenure. Instead, they document higher earnings quality associated with longer auditor tenure. They suggest that in the current audit environment, auditors with longer tenure, on average, put greater constraints on extreme management decisions in financial reporting, thus yielding evidence contrary to the claim that earnings quality deteriorates with extended auditor tenure.

Kaplan and Mauldin (2008) use an experimental setting to examine non-professional investors' judgments regarding audit firm rotation compared to audit partner rotation. The authors find no significant differences in non-professional investors' beliefs about auditor independence between a group that evaluated five-year audit firm rotation versus a group that evaluated five-year audit partner rotation (already required by SOX). In other words, investors' independence judgments for auditors are not incrementally different for audit firm rotation above and beyond the already required audit partner rotation. The already imposed partner rotation seems sufficient to create the same perceived benefits for independence, objectivity, and professional skepticism, with no additional costs. Additional analyses also suggest that non-professional investors seem to believe that auditors are more likely to be independent in the presence of a strong audit committee.

The Committee also believes that mandatory firm rotation can present a serious obstacle to auditors in conducting their independent and objective examination of financial reports. Companies may be reluctant to share information about future business plans that may have accounting implications with an outgoing auditor.

\section{What are the advantages and disadvantages of mandatory audit firm rotation? If there are potential disadvantages or unintended consequences, are there ways a rotation requirement could be structured to avoid or minimize them?}

Limited academic research suggests that mandatory audit firm rotation may have more potential disadvantages and unintended consequences than advantages. These issues relate to audit quality, audit costs, and audit specialization.

Audit quality. One of the consequences of mandatory firm rotation could be an increase in the number of audit failures. The Treadway Commission Report (Committee of Sponsoring Organizations of the Treadway Commission [COSO] 1987) suggests that a significant number of financial frauds involved companies that had recently changed their auditor, and others suggest that a greater proportion of audit failures occur on newly acquired audit clients (Berton 1991; Petty 
and Cuganesan 1996; Geiger and Raghunandan 2002; Johnson et al. 2002; Myers et al. 2003; Carcello and Nagy 2004; Stanley and DeZoort 2007; Davis et al. 2009; Gul et al. 2009). Further, Palmrose $(1986,1991)$ documents greater litigation risk to auditors in the early years of an engagement, and the AICPA's Quality Control Inquiry Committee of the Securities and Exchange Commission (SEC) Practice Section concluded that, in its analysis of 406 cases of alleged auditor failures between 1979 and 1991, audit failure occurred almost three times more often when the audit firm was engaged in its first or second year (AICPA 1992).

Audit costs. Mandatory firm rotation could increase audit fees. The Cohen Commission (1978) concluded that fees and time budgets were serious concerns that would be exacerbated by putting auditors in situations in which new clients are up for bid more often. There is both experimental and archival evidence that fee and time budget pressures can lead to reduced audit quality (Alderman and Deitrick 1982; DeZoort and Lord 1997; Coram et al. 2004; Ettredge et al. 2011). Further, auditors consistently discount audit fees for new engagements by an average of around 24 percent (Simon and Francis 1988; Ghosh and Pawlewicz 2009; Sankaraguruswamy and Whisenant 2009). However, firms might stop discounting to cover the increased costs. If one considers an audit fee as reflecting a set of services bundled across time, then either the total expected fee must increase given the reduced payback period, or costs must decrease, suggesting less effort and a loss of audit quality. The Committee assumes that neither is acceptable.

The increase in costs likely will be substantial for large, multinational firms with complex accounting issues because of the steep learning curve. In addition, small firms also will bear a substantial burden, as a portion of the incremental audit fees involved with a new client is fixed and/or sticky. Collectively, the cost to U.S. client-firms for audit services will increase as a result of audit firm rotation, and such costs will be passed on to shareholders and/or consumers.

Another factor to consider is that if audits go up for bid more often, large audit firms are better at bidding on new clients. If large audit firms are capable of obtaining more new clients because of their effective bidding, the end result could be even more market concentration than we currently have.

Audit specialization. Mandatory audit firm rotation could have the unintended consequence of increasing a "myopic" view of a client by the auditor. That is, if an auditor knows that after ten years, he or she will have to give up a client, would he or she an have incentive to invest in the necessary audit quality, in expanding and improving its quality control systems, in developing better and deeper relationships with a client? It is possible that, as a result of mandatory audit firm rotation, we will see a "commoditization" of audits. Some audit firms are specialized in certain industries, and mandatory rotation may result in a loss of that specialized knowledge. Munoz et al. (2001) show that broad experience facilitates accountants in developing appropriate knowledge structures, while specific domain experience helps them maximize their performance. As documented by Shelton (1999), experienced auditors (audit managers and partners) are less likely to be influenced by irrelevant information in their judgments than inexperienced auditors (audit seniors). Further, investors and information intermediaries associate auditor tenure with higher audit quality (Ghosh and Moon 2005), and auditors with longer tenure tend to place greater constraints on management's discretion (Myers et al. 2003).

Audits could become much less client-specific and more targeted to apply to larger groups of clients in order to minimize switching costs resulting from mandatory firm rotation. Auditors may have to become much more generalist than specialist in nature if their audit firm does not have a large presence in a particular industry, which would easily allow them to move across clients in the same specialty. Finally, recent regulatory financial reporting requirements, such as Sarbanes- 
Oxley (2002) and changing accounting standards (Financial Accounting Standards Board [FASB]/ International Financial Reporting Standards [IFRS]), have brought about an immediate and urgent need for audit specialists who have a more detailed understanding of a client's industry and operations in order to ensure that the client adheres to financial reporting requirements. Mandating audit firm rotation at this juncture would add additional complications.

To minimize these overwhelming disadvantages of changing auditors, the PCAOB also needs to consider whether mandatory firm rotation should be accompanied by complementary changes to existing requirements. For example, if, as some have suggested, audit risk is greater in the early years of an auditor-client relationship because of the lack of experience with the client, the PCAOB should consider additional quality control or other procedures to mitigate that risk. Such procedures could include (1) heightened internal supervision or oversight requirements for the first year or two of a new engagement, and (2) increased required communications between predecessor and successor auditors and the sharing of working papers. Overall, the Committee feels that such steps, while necessary to mitigate the negative outcomes associated with mandatory firm rotation, would further increase the costs and burden to companies in trying to implement the new requirement.

Firm rotation versus individual auditor rotation. Rotating audit firms may not always lead to the rotation of individual auditors, due to staffing constraints. For example, assume that the Detroit office of Deloitte had to rotate off the audit of General Motors (GM). The loss of this audit engagement would inevitably lead to a surplus of audit staff in Deloitte's Detroit office. The addition of this engagement at another audit firm would inevitably cause a shortage of staff in their Detroit office. Thus, auditors who specialize in the GM audit could move to the new audit firm, as a reallocation of resources at both firms would become necessary. It is well known that former Andersen auditors were hired by firms that picked up their Andersen clients. It is unlikely that the lead audit partner would come from another firm, but mandatory audit partner rotation is already in place. Small audits will not likely have a significant effect on staff turnover, but the rotation of large audit engagements could create a class of auditors who specialize in the audit of a specific company and rotate across firms with the audit client. Thus, it is not clear that mandatory firm rotation would have the desired effect on professional skepticism.

Because there appears to be little or no relevant empirical data directly on mandatory rotation available, should the Board conduct a pilot program so that mandatory rotation of registered public accounting firms could be further studied before the Board determines whether to consider developing a more permanent requirement? How could such a program be structured?

The Committee believes that the PCAOB should conduct a pilot program if the PCAOB decides to implement a mandatory audit firm rotation policy. The PCAOB could initiate a long-term trial Voluntary Auditor Rotation program, and modify it as needed during the trial period before adopting a permanent requirement. The PCAOB could urge audit committees and boards of directors to voluntarily rotate auditors every ten years or be required to file a statement with the PCAOB (on the audit firm's ten-year anniversary with the client) outlining their rationale for the continued engagement of their long-term auditors.

The voluntary nature of the requirement would provide audit committees, boards, and management teams that have legitimate reasons for not rotating auditors to explain those reasons to the PCAOB and to the public. By making this report a requirement, the PCAOB may symbolically, and perhaps actually, increase the ability of the audit committee to advocate for auditor rotation when prudent reasons dictate. 
The voluntary nature of the audit firm rotation requirement would enable issuers with legitimate reasons for not rotating auditors to explain those reasons. The issuers' shareholders can make their own determination about the legitimacy of reasons provided for non-rotation, and communicate their reactions either directly to the issuer, indirectly through public comment, or indirectly through their investment decisions.

Additionally, the Committee recommends that the Board undertake a study of mandatory audit firm rotation policies that exist at the state government level. For example, the state of Illinois requires all of its agencies to be audited annually by the Illinois State Auditor General, who hires special assistant auditors. The special assistant auditors are independent certified public accountants who conduct financial and compliance audits of state agencies. By Illinois law, each agency must change special assistant audit firms every six years. One very small study of Illinois universities that are audited under this six-year auditor rotation schedule found that auditors have the largest number of findings in the first year of the engagement, and the fewest number of findings in the last year of the engagement (Simmons et al. 2009). This finding suggests some improvement in audit quality in the early years of the engagement. The low level of audit quality findings in the final year of the engagement is consistent with the auditor having a low level of motivation in the year prior to rotating off of an audit engagement. One additional point about the mandatory audit rotation policy in Illinois involves cooperation between the predecessor and successor auditors. The Illinois Audit Act specifies that the audit working papers prepared by the CPA firms are the property of the State. Therefore, newly hired audit firms have complete access to the details of previous audit findings, which could reduce the start-up costs incurred by successor auditors.

While the regulatory environment is different for corporate clients and their auditors, the Committee encourages the PCAOB to consider creative ways to reduce start-up costs, if the PCAOB decides to implement a mandatory audit firm rotation policy.

According to the 2003 GAO Report, large firms estimated that a rotation requirement would increase initial year audit costs by more than 20 percent. What effect would a rotation requirement have on audit costs? Are there other costs the Board should consider, such as the potential time and disruption impact on company financial reporting staff as a result of a change in auditors? Are there implementation steps that could be taken to mitigate costs? The Board is particularly interested in any relevant empirical data commentators can provide in this area.

Our response to a previous question addresses some of these issues. It also is important to remember that the true cost of auditor switching is larger than just the audit fee, especially when the opportunity costs of manager and board time are considered.

A 2003 report by the Conference Board Commission on Public Trust and Private Enterprise recommended that audit committees consider rotation when, among other factors, "the audit firm has been employed by the company for a substantial period of time-e.g., over 10 years." To what extent have audit committees considered implementing a policy of audit firm rotation? If audit committees have not considered implementing such a policy, why not? What have been the experiences of any audit committees that have implemented a policy of rotation?

The Committee is not familiar with any research on experiences of audit committees that have implemented a rotation policy. However, the Committee agrees that the issue should be addressed with a survey of audit committee members. 
Are there alternatives to mandatory rotation that the Board should consider that would meaningfully enhance auditor independence, objectivity, and professional skepticism? For example, should broader alternatives be considered that relate to a company's requirement to obtain an audit, such as joint audits or a requirement for the audit committee to solicit bids on the audit after a certain number of years with the same auditor? Could audit committee oversight of the engagement be otherwise enhanced in a way that meaningfully improves auditor independence?

The Committee believes that audit committees should be more responsible for ensuring auditor independence, but does not have enough information on joint audits or a requirement for audit committees to solicit bids on the audit after a certain number of years with the same auditor to allow it to suggest other alternatives.

Should the Board continue to seek to address its concerns about independence, objectivity, and professional skepticism through its current inspection program? Is there some enhanced or improved form of inspection that could better address the Board's concerns? If mandatory rotation were in place, could an enhanced inspection, perhaps focused particularly on professional skepticism, serve as a substitute in cases in which it would be unusually costly, disruptive or otherwise impracticable to rotate auditors?

The Committee believes that the PCAOB should continue to address concerns about independence, objectivity, and professional skepticism through its inspections to achieve similar results without broader economic costs. Mandating firm rotation not only increases the overall costs of audits, but also creates uncertainty and disparity in audit quality. The PCAOB should focus its attention on the incentives that audit partners have to relax professional skepticism. The incentives to relax professional skepticism relate to how the profitability of an audit engagement factors into an audit partner's compensation. An audit partner has incentives to maintain good relations with the client, to reduce expenses related to the audit, and to minimize any impact of misstatements uncovered at the client. A profitable audit partner is not necessarily a professionally skeptical audit partner. Until those incentives align, there will be threats to auditor independence, regardless of whether firms are required to rotate periodically. Rather than implementing a costly directive such as mandatory firm rotation, the PCAOB may be better served by looking at individual incentive structures that lead to unintended reductions in professional skepticism. Until audit partners are evaluated on and rewarded for their professional skepticism, there always will be threats to professional skepticism.

It may be helpful to consider other professions and how they are rewarded for their professional skepticism. For example, professional reporters make careers for themselves by uncovering a big story (e.g., Woodward and Bernstein). Professional prosecutors make careers for themselves by prosecuting high-profile cases. However, audit partners are not rewarded in the same manner for being skeptical. It is an open question as to whether it is good public policy that auditors are as skeptical as investigative reporters or professional prosecutors, but it is a question worth asking.

\section{Section IV. Possible Approaches to Rulemaking}

A. Term of Engagement

1. If the Board determined to move forward with development of a rotation proposal, what would be an appropriate term length? 
If the Board decides to move forward with a rotation proposal, the Committee suggests that the term should be long enough for the company to recover its "start-up" costs. The Committee recommends a term of no less than ten years.

2. Should different term lengths for different kinds of engagements be considered? If so, what characteristics, such as client size or industry, should this differentiation be based on?

If the Board decides to move forward, it would be advisable to have varying term lengths depending on the size of the audit engagement relative to the size of the audit firm (or the office where the audit is performed). Such distinctions would be similar to differentiating between large accelerated filers, accelerated filers, and non-accelerated filers when assessing an appropriate filing window. Another factor to consider is the availability of suitable competitors with appropriate audit expertise. For example, if an audit engagement requires specialized industry knowledge and other audit firms in the city are not likely to have specialists in that area, then rotating audit firms would not be advisable.

Mandatory rotation also could be required for companies that have significant prior misstated financial statements, auditors with long tenure, and for which the PCAOB has identified significant issues that can reasonably be associated with tenure.

3. Does audit effectiveness vary over an auditor's tenure on a particular engagement? For example, are auditors either more or less effective at the beginning of a new client relationship? If there is a "learning curve" before auditors can become effective, generally how long is it, and does it vary significantly by client type?

As mentioned earlier, prior research suggests an association between new audits and audit failures (Berton 1991; Petty and Cuganesan 1996; Geiger and Raghunandan 2002; Johnson et al. 2002; Myers et al. 2003; Carcello and Nagy 2004; Stanley and DeZoort 2007; Davis et al. 2009; Gul et al. 2009), but whether that evidence is applicable to mandatory firm rotation is not clear.

For those that currently rotate auditors voluntarily, the PCAOB could conduct a study (or sponsor one) that examines whether new auditor-client relationships result in fewer problems, fewer audit adjustments, and/or fewer audit failures.

4. Some have also suggested that, in addition to being less effective at the beginning of an engagement, an auditor may be less diligent toward the end of the allowable term. On the other hand, others have suggested that auditors would be more diligent toward the end of the allowable term out of concern about what the replacement auditor might find. Would auditors become more or less diligent toward the end of their term? Does the answer depend on the length of the term?

The accountability literature would suggest that auditors would be more diligent toward the end of the audit term. This is because auditors would feel greater accountability for the quality of their work when they know that another auditor will be replacing them in the next year. For instance, Lord (1992) finds that experienced audit managers were less likely to issue an unqualified opinion when they were made accountable for their decisions. Similarly, DeZoort et al. (2006) show that auditors who are under higher levels of accountability pressure, by way of having to provide feedback and justification, provide more conservative materiality judgments and have less judgment variability. However, the advent of PCAOB inspections and audit partner rotation plays the same role of increasing accountability without the loss of audit effectiveness and efficiency due to mandatory audit firm rotation. In fact, changing firms may reduce this sense of accountability, as audit partners may feel more accountable to fellow partners (i.e., shame) than to unknown partners of another firm. 
5. How much time should be required before a rotated firm could return to an engagement?

Considering the small number of audit firms that are truly available to large companies, setting a short period would be more reasonable. The start-up costs are sufficiently large that companies will most likely opt to keep the successor auditor for as long as they can before mandatory rotation. Thus, the PCAOB should not unduly further restrict firms' choice of auditors.

B. Scope of Potential Requirement

6. Should the Board consider requiring rotation for all issuer audits or just for some subset, such as audits of large issuers? Should the Board consider applying a rotation rule to some other subset of issuer audits? For example, are there reasons for applying a rotation requirement only to audits of companies in certain industries?

As previously discussed, the Board should consider if viable alternatives exist for each audit client based on industry and location. Negative unintended consequences from mandatory audit firm rotation are likely positively associated with client size and industry specialization. In other words, the audit quality of large audit clients in specialized industries is more likely to suffer from mandatory audit firm rotation.

C. Transition and Implementation Considerations

7. To what extent would a rotation requirement limit a company's choice of an auditor? Are there specific industries or regions in which a rotation requirement would present particular difficulties in identifying an auditor with the necessary skills and expertise? Is it likely that some smaller audit firms might decide to leave the public company audit market due to the level of uncertainty regarding their ongoing client portfolios?

As discussed above, market concentration and loss of specialization are possible disadvantages of a mandatory firm rotation rule.

8. If rotation would limit the choice of auditors, are there steps that could be taken to allow a company sufficient time to transition out of non-audit service arrangements with firms that could be engaged to perform the audit? Are there other steps that could be taken to address any limitation on auditor choice?

Consider an example in which a company uses PricewaterhouseCoopers (PwC) for audit services and Ernst \& Young (EY) for nonaudit services. If rotation is required and the company must rotate away from PwC, the company must either choose between KPMG and Deloitte (assuming that only a Big 4 firm is an option) or must also switch its nonaudit service provider to include EY as a potential audit provider.

An indirect cost to audit firms is that companies may choose to hire consulting (versus audit) firms to provide nonaudit services to avoid the above loss of choice. This potential reduction of consulting services for Big 4 audit firms might represent an additional positive step supporting auditor independence; however, it may lead audit firms to shy away from performing audit services.

A transition period allowing one firm to perform both audit and nonaudit services does not seem to be consistent with the goal of increased auditor independence (to the extent that one believes joint provision reduces independence).

9. If rotation were required, would audit firms have the capacity to assign appropriately qualified personnel to new engagements? If they do not currently have that 
capacity, could firms develop it in order to be able to compete for new clients, and would they do so?

If the Board determined to move forward, then it would need to effectively manage the transition to avoid mass rotation in a single year, and allow firms to structure plans to transition effectively and prevent any capacity issues.

10. Would rotation create unique challenges for audits of multinational companies? For voluntary rotations that have taken place, what have been the implementation and cost issues and how have they been managed?

11. Would increased frequency of auditor changes disrupt audit firms' operations or interfere with their ability to focus on performing high quality audits? How would any such disruption vary by firm size? For example, would a rotation requirement pose fewer or more implementation issues for small firms than for large ones?

12. Would audit firms respond to a rotation requirement by devoting fewer resources to improving the quality of their audits? Would firms focus more on non-audit services than on audit services?

There are no empirical data on how auditors adjust their revenue mix in response to regulatory changes. Hypothetically, in response to the restrictions of mandatory audit firm rotation, auditors could start switching to providing nonaudit services, which would not be subject to audit firm rotation requirements. However, in our view, it is unlikely that such changes would be massive, since the accounting firms had to significantly downsize their consulting practices following independence scandals of the early 2000s, and as a result of the Sarbanes-Oxley Act. Auditing will be their "bread and butter," regardless. The question is whether mandatory audit firm rotation could negatively affect accounting firms' investments in their audit practices.

The table below provides a breakdown of the total fees paid during the 2000-2010 period by the type of accounting firm, using Audit Analytics and Compustat data.

\section{Firm}

Arthur Andersen (before dissolution)

Ernst \& Young

Deloitte

KPMG

PwC

All others

Total
Aggregate audit fees during 2000-2010

$\$ 837,242,778$

$\$ 21,861,321,402$

$\$ 20,272,753,804$

$\$ 18,439,156,932$

$\$ 28,177,819,504$

$\$ 4,193,322,039$

$\$ 93,781,616,459$
Aggregate Nonaudit fees during 2000-2010

$\$ 1,647,635,089$

$\$ 8,423,968,775$

$\$ 8,413,020,382$

\$ $6,827,805,949$

$\$ 13,551,710,365$

\$ $915,698,827$

$\$ 39,779,839,387$

As is evident for almost all firms above, with the exception of Arthur Andersen, audit fees significantly exceed nonaudit fees; in aggregate, audit fees exceed nonaudit fees by a ratio of about 2.3:1. It is hard to imagine that there will be a wholesale switch from provision of audit services to provision of nonaudit services, even if mandatory rotation is instituted. In addition, we are aware of no empirical evidence suggesting that auditors would switch to greater provision of nonaudit services as a result of natural rotation (i.e., resignations and dismissals of auditors).

However, it is possible that over time, we could see a recurring trend to the growth of nonaudit practices within accounting firms, because those practices would not be subject to mandatory rotation requirements. If accounting firms were to turn more aggressively to provision of nonaudit 
services when faced with rotation demands, one possible positive consequence would be clients' greater ability to acquire nonaudit services from other firms, because under current SOX provisions, firms are prohibited from providing many types of nonaudit services, and any provision of permitted nonaudit services has to be approved by the audit committee (Chen et al. 2008).

Regardless of what may happen, one could still ask a reasonable question; specifically, is provision of nonaudit services by itself "bad"? Relevant research is mixed; however, it seems that the majority of studies support the view that nonaudit services are not necessarily harmful. With respect to negative evidence, prior research provides some evidence that nonaudit services result in greater economic bonding between auditors and their clients. In particular, auditors are less likely to resign from clients paying higher nonaudit fees; however, this effect is less pronounced after passage of the Sarbanes-Oxley Act (Chen et al. 2008). Correspondingly, clients are more likely to fire auditors that charge higher audit fees, with this effect more pronounced among smaller clients (Ettredge et al. 2007).

Nonaudit fees also can have positive "spillover" effects, whereby knowledge gained from nonaudit services helps improve the quality of audit engagements. For example, Lim and Tan (2008) show that this spillover effect is more pronounced among specialist auditors. One potential explanation for this finding is that industry specialists benefit more from knowledge gleaned from nonaudit services (e.g., IT work) and, thus, can more efficiently transfer such learning to their audit engagements. However, Frankel et al. (2002) also raise the possibility that nonaudit services may have negatively affected auditor objectivity in the pre-SOX period, as manifested in a higher level of earnings management. Ferguson et al. (2004) find similar evidence of a positive association of earnings management and nonaudit services in the U.K. market. At the same time, Frankel et al.'s (2002) work has been challenged by several other studies that failed to find a similar relation between nonaudit fees and earnings management (e.g., Ashbaugh et al. 2003; Chung and Kallapur 2003; Larcker and Richardson 2004).

Therefore, it seems that while some studies support the view that nonaudit services increase the level of economic bonding with clients, no clear evidence exists supporting this view. Nonaudit services also could be beneficial in terms of "knowledge spillovers." Thus, even if accounting firms increase their investments in nonaudit services, research does not provide clear evidence that this will be undesirable.

Because nonaudit fees tend to originate more from highly specialized projects and have been cited as being more lucrative (Chen et al. 2008), we can see a renewed trend to invest more human and physical capital into nonaudit services in general. In other words, mandatory audit firm rotation could contribute to a change in the general profile of many accounting firms to more of a consulting or an advisory service, where auditing will be less dominant. However, this change will likely take a very long time. If this change occurs, it is hard to tell whether it will necessarily be negative. Its effect will depend on the relative trade-off between benefits of mandatory audit firm rotation in the form of greater auditors' objectivity and independence, and a possible long-term cost of under-investment into auditing services.

13. Would rotation have any effect on the market for non-audit services? Would any such effect be harmful or beneficial to investors?

14. Some have expressed concern that rotation would lead to "opinion shopping," or that in competing for new engagements firms would offer favorable treatment. Others have suggested that rotation could be an antidote to opinion shopping because companies would know that they could not stick with a firm promising favorable treatment forever. Would opinion shopping be more or less likely if 
rotation were required? If rotation limits auditor choice, could it at the same time increase opinion shopping?

15. What effect would a rotation requirement have on competition for audit engagements? If competition would be increased, how might that affect audit quality?

Mandatory firm rotation might have both short- and long-term effects on competition. In the short term, it might force increased competition. However, in the long term, companies will have at least one less audit firm from which to choose each year of rotation. In addition, if firms choose to switch their primary function from the performance of audit services to nonaudit services, companies also will face a reduced number of firms from which to choose.

\section{REFERENCES}

Alderman, C. W., and J. W. Deitrick. 1982. Auditors' perceptions of time budget pressures and premature sign-offs. Auditing: A Journal of Practice \& Theory 1 (2): 54-68.

American Institute of Certified Public Accountants (AICPA). 1992. Statement of Position Regarding Mandatory Rotation of Audit Firms of Publicly Held Companies. New York, NY: AICPA.

Ashbaugh, H., R. LaFond, and B. Mayhew. 2003. Do nonaudit services compromise auditor independence? Further evidence. The Accounting Review 78 (3): 611-639.

Berton, L. 1991. GAO weighs auditing plan for big banks. Wall Street Journal (March 27): A3.

Carcello, J., and A. Nagy. 2004. Audit firm tenure and fraudulent financial reporting. Auditing: A Journal of Practice \& Theory 23 (2): 55-70.

Chen, L., R. Frankel, and N. Jenkins. 2008. Quasi-Rents and Auditor Turnover. Working paper, Washington University.

Chung, H., and S. Kallapur. 2003. Client importance, nonaudit services, and abnormal accruals. The Accounting Review 78 (4): 931-955.

Cohen Commission. 1978. Commission on Auditors' Responsibilities, Report, Conclusions and Recommendations. New York, NY: AICPA.

Committee of Sponsoring Organizations of the Treadway Commission (COSO). 1987. Report of the National Commission on Fraudulent Financial Reporting. Available at: http://www.coso.org/publications/ncffr.pdf

Coram, P., J. Ng, and D. R. Woodliff. 2004. The effect of risk of misstatement on the propensity to commit reduced audit quality acts under time budget pressure. Auditing: A Journal of Practice \& Theory 23 (2): 159-167.

Davis, R., B. S. Soo, and G. M. Trompeter. 2009. Auditor tenure and the ability to meet or beat earnings forecasts. Contemporary Accounting Research 26 (2): 517-548.

DeZoort, T., and A. T. Lord. 1997. A review and synthesis of pressure effects research in accounting. Journal of Accounting Literature 16: 28-85.

DeZoort, T., P. Harrison, and M. Taylor. 2006. Accountability and auditors' materiality judgments: The effects of differential pressure strength on conservatism, variability, and effort. Accounting, Organizations and Society 31 (4/5): 373-390.

Ettredge, M., C. Li, and S. Scholtz. 2007. Audit fees and auditor dismissals in the Sarbanes-Oxley era. Accounting Horizons 21 (4): 371-387.

Ettredge, M., C. Li, and E. Emeigh. 2011. Fee Pressure and Audit Effort During the "Great Recession" of 2007-2009. Working paper, The University of Kansas.

Ferguson, M. J., G. S. Seow, and D. Young. 2004. Nonaudit services and earnings management: U.K. evidence. Contemporary Accounting Research 21 (4): 813-841.

Frankel, R., M. Johnson, and K. Nelson. 2002. The relation between auditors' fees for non-earnings management and earnings management. The Accounting Review 77: 71-105.

Geiger, M., and K. Raghunandan. 2002. Auditor tenure and audit reporting failures. Auditing: A Journal of Practice \& Theory 21 (1): 68-78.

Ghosh, A., and D. Moon. 2005. Auditor tenure and perceptions of audit quality. The Accounting Review 80: 585-612. 
Ghosh, A., and R. Pawlewicz. 2009. The impact of regulation on auditor fees: Evidence from the Sarbanes-Oxley Act. Auditing: A Journal of Practice \& Theory 28 (2): 171-197.

Gul, F. A., S. Y. K. Fung, and B. Jaggi. 2009. Earnings quality: Some evidence on the role of auditor tenure and auditors' industry expertise. Journal of Accounting and Economics 47 (3): 265-287.

Johnson, V., I. Kurana, and K. Reynolds. 2002. Audit-firm tenure and the quality of financial reports. Contemporary Accounting Research 19 (4): 637-660.

Kaplan, S., and E. Mauldin. 2008. Auditor rotation and the appearance of independence: Evidence from nonprofessional investors. Journal of Accounting and Public Policy 27: 177-192.

Larcker, D., and S. Richardson. 2004. Fees paid to audit firms, accrual choices, and corporate governance. Journal of Accounting Research 42 (3): 625-658.

Lim, C., and H. Tan. 2008. Non-audit service fees and audit quality: The impact of auditor specialization. Journal of Accounting Research 46 (1): 199-246.

Lord, A. 1992. Pressure: A methodological consideration for behavioral research in auditing. Auditing: A Journal of Practice \& Theory 11 (2): 90-109.

Munoz, S., W. Kinney, and S. Bonner. 2001. The effects of domain experience and task presentation format on accountants' information relevance assurance. The Accounting Review 76 (3): 405-430.

Myers, J., L. Myers, and T. Omer. 2003. Exploring the term of the auditor-client relationship and the quality of earnings: A case for mandatory auditor rotation? The Accounting Review 78 (3): 779-799.

Palmrose, Z.-V. 1986. Litigation and independent auditors: The role of business failures and management fraud. Auditing: A Journal of Practice \& Theory 6 (2): 90-103.

Palmrose, Z.-V. 1991. Trials of legal disputes involving independent auditors: Some empirical evidence. Journal of Accounting Research 29 (Supplement): 149-185.

Petty, R., and S. Cuganesan. 1996. Auditor rotation: Framing the debate. Australian Accountant 66 (May): 40-41.

Sankaraguruswamy, S., and S. Whisenant. 2009. Pricing Initial Audit Engagements: Empirical Evidence Following Public Disclosure of Audit Fees. Working paper, University of Houston.

Shelton, S. 1999. The effect of experience on the use of irrelevant evidence in auditor judgment. The Accounting Review 74: 217-224.

Simmons, T. N., M. L. Costigan, and L. M. Lovata. 2009. Mandatory audit firm rotation: Evidence from Illinois state universities. Academy of Accounting and Financial Studies Journal 13 (3): 123-131.

Simon, D., and J. Francis. 1988. The effects of auditor change on audit fees: Tests of price cutting and price recovery. The Accounting Review 63 (2): 255-269.

Stanley, J. D., and F. T. DeZoort. 2007. Audit firm tenure and financial restatements: An analysis of industry specialization and fee effects. Journal of Accounting and Public Policy 26 (March/April): 131-159.

U.S. House of Representatives. 2002. The Sarbanes-Oxley Act of 2002. Public Law 107-204 [H. R. 3763]. Washington, D.C.: Government Printing Office. 